Sinop Üniversitesi

Sosyal Bilimler Dergisi
Sinop Üniversitesi Sosyal Bilimler Dergisi, 4 (2), 513-526

Geliş Tarihi:23.05.2020 Kabul Tarihi: 10.07.2020 Yayın:Temmuz-Aralık 2020 Yayın Tarihi:31.12.2020 https://doi.org/10.30561/sinopusd.741893

\title{
SANAL ORTAM YALNIZLIĞI VE ÖZGÜVEN ÜZERINE BIR ARAŞTIRMA
}

\author{
Müjdat YEŞILLDAL* \\ Handan ERTAŞ*
}

\section{$\ddot{O} \mathbf{z}$}

Günümüzde internet hayatın her alanına nüfuz etmiş haldedir. Bu etkinin bir sonucu olarak sanal ortam yalnızlığı ve bu yalnızlık ile birlikte özgüven sorunu yaşanmaktadır. Araştırma kapsamında üniversite öğrencilerindeki sosyal medya kullanımının artmasından dolayı oluşan sanal ortamın yalnızlığı ve bu yalnızlığın özgüvenle arasındaki ilişki, bu ilişkiyi etkileyen faktörler ele alınmıştır. Araştırmada veri toplama aracı olarak sanal ortam yalnızlık ölçeği ve özgüven ölçeği kullanılmıştır. Araştırmada nicel araştırma deseni kullanılmış olup, Sağlık Bilimleri Fakültesi, Hemşirelik Fakültesi ile Sağlık Hizmetleri Meslek Yüksekokulunda öğrenim gören 390 öğrenciye anket uygulanmıştır. Bulgulardan elde edilen sonuca göre sanal ortam yalnızlı̆̆ ile özgüven arasında negatif yönlü zayıf düzeyde bir ilişki tespit edilmiştir. Sanal ortam yalnızlığı ve özgüven cinsiyete göre farklılaşırken, diğer değişkenler ile arasında anlamlı bir farklılık tespit edilememiştir.

Anahtar Kelimeler: Sanal ortam yalnızlığı, Özgüven, Sosyal ağ.

* Bu araştırmanın verileri 2019 yılında toplanmıştır.

* Ar. Gör., Selçuk Üniversitesi, Sağlık Bilimleri Fakültesi Sağlık Yönetimi Bölümü, mujdatyesildal@gmail.com, https://orcid.org/0000-0003-1286-903X.

* Doç. Dr., Selçuk Üniversitesi, Sağlık Bilimleri Fakültesi Sağlık Yönetimi Bölümü, handanertas@selcuk.edu.tr, https://orcid.org/0000-0003-1794-0296. 


\title{
A Research on Virtual Environment Loneliness and Self-Confidence
}

\begin{abstract}
Today, the internet has penetrated all areas of life. As a result of this effect, virtual environment loneliness and self-confidence are experienced with this loneliness. Within the scope of the research, the loneliness of the virtual environment caused by the increase in the use of social media in university students and the relationship between this loneliness and self-confidence, and the factors affecting this relationship were discussed. In the research, the virtual environment loneliness scale and self-confidence scale were used as data collection tools. The quantitative research design was used in the research and a questionnaire was applied to 390 students studying at the Faculty of Health Sciences, Faculty of Nursing and Vocational School of Health Services. According to the results obtained from the findings, a weak negative relationship was found between virtual loneliness and self-confidence. While virtual environment loneliness and self-confidence differ according to gender, no significant difference was found between other variables.
\end{abstract}

Keywords: Virtual environment loneliness, Self-confidence, Social network.

\section{Giriş}

Bilişim teknolojilerinin uygulama alanları üzerindeki olumsuz etkileri yadsınamaz bir gerçektir. Hayatın her alanında bilişim teknolojilerinden yararlanmayan kişiler neredeyse yok denecek kadar azdır. Hayatımıza son yıllarda fazlasıyla yenilikler getiren bu araçlar aynı zamanda sosyal alanlardan çekilme gibi sorunlar doğurmuştur. Sosyal alanda arkadaşlık, dostluk ve yakın çevre kurmakta zorlanan gençler bu eksiklikleri nedeniyle gerek fiziksel gerekse psikolojik olarak sıkıntılar yaşatmaktadır. Bu nedenle gençler bu sıkıntılarla baş etmek, yalnızlıklarını giderebilmek, sosyal ilişkilerindeki zayıflıkları yok edebilmek için sosyal medya paylaşım sitelerine başvurmaktadır. Sanal ortamlarda sosyalleşmenin sonucu olarak gerçek hayattan soyutlanma gerçekleşmektedir. Günümüzde bakıldığında kendi çevre- 
sinde ve etrafinda yeteri kadar sosyal ağı bulunmayan, arkadaş çevresi ve hayatta daimî dostluklar edinemeyen gençlerimizin daha çok sanal ortamlarda, sanal dünyalarını genişleterek kendilerine adeta dünyamızdan ayrı olarak yeni bir sosyal olmayan dünya yarattı̆̆ını ve sanal ortamların sosyal gençleri olduğunu görebiliriz. $\mathrm{Bu}$ sayede içlerindeki, hislerindeki yalnızlık duygularını yok etmeye çalıştıkları görülmektedir. İç dünyasında bu kadar yalnız hissederken kendine bunu belli etmeden sosyal bir çevre oluşturmak için sanal ortamda aktif olan gençler, bu çalışmanın ana konusunu oluşturmaktadır.

\section{Sanal Ortam Yalnızlığı}

Kişiye has olan ve psikolojik açıdan incelenmesi gereken yalnızlık, kişinin kurduğu sosyal ilişkilerden memnun olmaması, olamaması sonucu ortaya çıkan bir durumdur. Weiss (1973) yalnızlık üzerine yazmış olduğu kitabında yalnızlığı sosyal ve duygusal yalnızlık olarak iki türde ele almıştır. Duygusal yalnızlıkta bireylerin sevdikleri birini kaybetmesi yahut onların eksikliğini duyması söz konusu olmaktayken, sosyal yalnızlıkta ise bireyin daha çok toplumla olan ilişkilerinde, sosyal bağlarında görülen zayıflıktan ortaya çıkan bir durum söz konusudur. Buradan anlaşılacağı üzere duygusal yalnızlı bireyin bir kişiye karşı hissettiği yalnızlık olabilecekken, sosyal yalnızlık bireyin çevresi ile eksik iletişim ve eksik bağlarından dolayı ortaya çıkabilecek bir durum olarak ifade edilmektedir (Kabaklı Çimen, 2018). Yalnızlık her dönemde görülebilecek bir olgu iken genel ve yoğun olarak genç yaşlardaki insanlarda görülme sıklığı daha yüksektir. İnsan hayatında samimi, sıkı dostlar ve sıkı bağlar kurmak için çabalar. Bunu karşılamak için başkaları ile uygun sosyal ilişkiler kurma olgunluğuna sahip olmadıkları zaman, yalnızlık hissedebilmektedirler (Erözkan, 2009).

Gençler özellikle sosyal hayatın en hareketli, en karmaşık ve dolu olduğu zamanlarda, kişiliklerinin tam oturmaya, yeni yeni kişiliklerinin tamamlanmaya başladığı bir dönemde üniversite eğitimi görmeye başlamaktadırlar. Özelikle üniversite yerleşkeleri ile yaşanılan şehirler arasındaki mesafe, ders yükümlülüğü veya 
okumak için başka bir şehre geçiş süreçlerinde öğrenciler sosyal çevrelerini değiştirmek zorunda kalmaktadır. Bu kapsamdan hareketle üniversite öğrencilerinin yalnızlık düzeyleri üzerine çalışmalar yapılmaktadır. Sınırların olmadığı bir ortamın içinde birey ihtiyaç olarak gördüklerinin arkasından giderken zamanla neyin ihtiyaç, neyin istek veya onu çok ilgilendirmeyen bir konu olduğunu karıştırma veya başka işlerle meşgul olma durumuna gelebilmektedir. Böylece toplumdaki ilişkileri ve sorumlulukları olan birey kendisini bireysel anlamda meşgul eden ortamlarda zaman geçirmeye başladıkça toplumdan uzaklaşmaya da başlayabilmektedir. Kişinin internetin başında geçirdiği zaman arttıkça toplum hayatından uzaklaştığı, sosyal ilişkilerinin zayıfladığı, aile ve çevre ile daha az iletişimde bulunduğundan dolayı kendini daha yalnız hissettiği ifade edilmektedir (Kabaklı Çimen, 2018). Yani kişi sanal ortamlar ve internet başında geçirdiği zamanla aslında sosyalleştiğini, eksik olan sosyal parçasını tamamladığını düşünürken aslında elinde olan aile bağları, gerçek elle tutulur, somut arkadaş ve sosyal ağlarından kopmakta olduğunun farkında değildir (Özdemir vd., 2017).

\section{2. Özgüven}

Özgüven; kısaca bireyin kendisiyle barışık olması ve kendini olduğu gibi kabul etmesi durumu olarak tanımlanabilir. Birey bu duygu ve olguyu kazanırken kendi hal ve hareketlerinin davranışlarının olumlu ve olumsuz yönlerini bilmektedir. Korkuları ve olumsuz yönleri ile yüz yüze gelerek yetenek ve davranışlarının farkına varır ve kendini tarafsız olarak tanır (Kocaarslan, 2009). Özgüven kritik ve önem oranı yüksek bir özelliktir, yaşamla ve problemlerle realist bir şekilde baş etmemizi sağlar. Özgüven kazanma süreci, yaşamın önemli zorluklarına karşı başa çıkma gücüne sahip ve mutlu olmaya layık bir kişi olma deneyimidir. Bu egemenlik ruhunun olması veya olmaması, kişinin dış dünyası ile olan ilişkilerinde en önemli etkenlerden birisidir (Kurtuldu, 2007). Özgüven kişinin davranışlarını, tavırlarını, hareketlerini belirleyen kendi hakkındaki görüşleri olarak sayılabilir. Yüksek özgüvenli kendini değerli ve saygın hissedenlerdir, savunmacı özgüven ise 
kendini değersiz hisseden fakat bu hissi kabul edemediği için savunma yöntemlerine başvurandır şeklinde tanımlanabilir (Çelik, 2014). Özgüven, davranış ve hareketlerin en önemli belirleyicisi sayılabilir. Özgüvenin etken olduğu, bireyin kendine ait olumlu düşünce ve yargılarının olması, olayları ve kendini kontrol edebileceğine inanması, kendini değerli bulması ve beğenmesi, yeterli düzeyde olduğunu düşünmesi, kendi değerinin farkında olması, kendisiyle barışı olması, kendini olduğu gibi kabul etmesi, kendini tanıması gibi durumlarla ilgili bir kavramdır. Genel olarak özgüven kişinin kendi yapabildiklerini, hislerini bilmesi, kendini beğenmesi ve kendine inanması olarak tanımlamıştır (Günalp, 2007).

Lindenfield (1997) özgüveni, iç özgüven ve dış özgüven şeklinde ikiye ayırmaktadır. İç özgüven, bireyin kendinden memnun ve barışık olduğuna dair inancı ve bu konuda hissettikleri; dış özgüven ise, dış ortama kendinden emin olarak verdiği görüntü ve davranışlardır. Özgüven iç ve dış özgüvenin toplamı olarak ifade edilmektedir. İç özgüven, kişinin kendi özelliklerini tanıması ve olumlu karşılaması ve bundan dolayı memnun olması; dış özgüven ise iç özgüven duygusuyla dışarıya yansıttığımız görüntü olarak tanımlanabilir. İç özgüven; kendini tanıma, kendini sevme, kendine açık hedefler koyma ve pozitif düşünmedir. Dış özgüven ise; iletişim, anlatabilme, duygularını egemenlik altına alabilmesidir (Akt. Bilgin, 2011). Göknar'a (2010) göre insan doğuştan farklı zekâ düzeylerine ve yeteneklerine sahiptir. İnsan dünyaya hiçbir zaman özgüvenden yoksun veya özgüvenli bir birey olarak dünyaya gelmez. Özgüven oluşumu tamamen yaşamla, yaşanan olaylarla, hayatın ilerleyişi ile ilgili bir durumdur. Güvenin, sevginin, kabul edilmenin her birimizin özünde olduğunu düşünür isek, özgüven oluşumunun da çevrenin etkisi ile ve zamanla oluştuğunu söyleyebiliriz (Günalp, 2007).

\section{Yöntem}

\subsection{Araştırmanın Amacı ve Soruları}

$\mathrm{Bu}$ araştırmanın amacı sağlık bilimleri alanında öğrenim gören öğrencilerin sanal ortam yalnızlığı ile özgüven seviyeleri arasındaki ilişkiyi incelemektir. Bu amaca ulaşma sürecinde aşağıdaki araştırma sorularına cevap aranmıştır: 
1. Sanal Ortam Yalnızlığı ile yaş, öğrenim görülen birim ve aylık gelir durumu gibi demografik değişkenler arasında istatistiksel olarak bir ilişki var mıdır?

2. Sanal Ortam Yalnızlığı ile yaş, öğrenim görülen birim ve aylık gelir durumu gibi demografik değişkenler arasında istatistiksel olarak nasıl bir ilişki bulunmaktadır?

3. Özgüvenin ile yaş, öğrenim görülen birim ve aylık gelir durumu gibi demografik değişkenler arasında istatistiksel olarak bir ilişki var mıdır?

4. Özgüvenin ile yaş, öğrenim görülen birim ve aylık gelir durumu gibi demografik değişkenler arasında nasıl bir ilişki bulunmaktadır?

5. Sanal Ortam Yalnızlı̆̆ ile Özgüven arasında ilişki var mıdır?

6. Sanal Ortam Yalnızlığı ile Özgüven arasında nasıl bir ilişkibulunmaktadır?

\subsection{Araştırmanın Tipi}

Araştırmada nicel araştırma tarama tipi kullanılmış olup; tanımlayıcı nitelikte bulgular ortaya konulmuştur.

\subsection{Veri Toplama Araçları}

Veri toplama aracı olan anket formu üç bölümden oluşmaktadır. İlk bölümde araştırmacı tarafından demografik özellikleri belirlemek için hazırlanan cinsiyet, yaş, öğrenim görülen birim, gelir durumu ve barınma durumunu belirlemeye yönelik sorular bulunmaktadır. İkinci bölümde Korkmaz ve diğerleri (2014) tarafindan geliştirilen 20 maddelik 3 alt boyutlu Sanal Ortam Yalnızlık Ölçeği (SOYÖ) kullanılmıştır. Ölçme aracı üç faktör altında toplanmaktadır. Ölçeğe ait Cronbach's Alpha katsayısı 0,932 olarak tespit edilmiştir. Üçüncü bölümde ise Akın (2007) tarafından geliştirilen iki faktörden oluşan Özgüven Ölçeği kullanılmıştır. Özgüven ölçeğine ait Cronbach's Alpha katsayısı 0,852 olarak tespit edilmiştir.

\section{4. Çalışma Grubu}

Araştırma evrenini Selçuk Üniversitesi Alaaddin Keykubat Kampüsünde bulunan Sağlık Bilimleri Fakültesi, Hemşirelik Fakültesi ile Sağlık Hizmetleri Meslek Yüksekokulunda öğrenim görmekte olan 4892 üniversite öğrencisi oluşturmaktadır. Belirli evrenler için örneklem hesaplama yöntemine göre $\pm \% 5$ kabul 
edilebilir hata oranına göre \%95 güven aralığında önerilen örneklem büyüklüğü 384 kişidir (Altunışık vd. 2012). Örneklem öğrenim görülen birimlere göre tabaka11 örnekleme deseniyle oluşturulmuştur. Araştırmaya katılan öğrencilere ait tanımlayıcı bulgular Tablo 1'de verilmiştir.

Tablo 1: Katılımcıların Tanımlayıcı Özelliklerine İlişkin Bulgular

\begin{tabular}{|c|c|c|c|}
\hline \multicolumn{2}{|l|}{ Özellikler (n=390) } & \multirow{2}{*}{$\frac{\mathbf{n}}{258}$} & \multirow{2}{*}{$\frac{\%}{66,2}$} \\
\hline \multirow[b]{2}{*}{ Cinsiyet } & Kadın & & \\
\hline & Erkek & 132 & 33,8 \\
\hline \multirow{2}{*}{$(20,93 \pm 1,92)$} & Ortalama altındakiler & 178 & $\overline{45,6}$ \\
\hline & Ortalama üstündekiler & 212 & 54,4 \\
\hline \multirow{3}{*}{ Ö̈̆renim Görülen Birim } & Sağlık Bilimleri Fakültesi & 130 & 33,3 \\
\hline & Hemşirelik Fakültesi & 130 & 33,3 \\
\hline & Sağlık Hizmetleri MYO & 130 & 33,3 \\
\hline \multirow{4}{*}{ Gelir Durumu } & $0-2000 €$ & 76 & 19,5 \\
\hline & 2001-3000€ & 124 & 31,8 \\
\hline & 3001-4000 £ & 103 & 26,4 \\
\hline & 4001 £ ve üzeri & 87 & 22,3 \\
\hline \multirow{3}{*}{ Barımma Durumu } & Ailesiyle birlikte & 265 & 67,9 \\
\hline & Arkadaşlarıyla birlikte & 104 & 26,7 \\
\hline & Yalnız & 21 & 5,4 \\
\hline
\end{tabular}

Araştırmaya katılan öğrenciler ait temel demografik bulgular Tablo 1'de sunulmuştur. Öğrencilerin \%66,2'si kadın, \%31,8'i 2001-3000 TL arasında gelire, \%26,1'i 3001-4000 TL gelire sahipken \%67,9 'u ailesiyle birlikte yaşamaktadır. Katılımcılara ait ortalama yaş $20,93 \pm 1,92$ olarak tespit edilmiştir. Öğrenim görülen birimler homojen şekilde dağılmaktadır.

\subsection{Verilerin Toplanması ve Analizi}

Veriler araştırmacı tarafından Mayıs-Haziran 2019 tarihlerinde yüz yüze anket yöntemiyle toplanmıştır. Bir anketin doldurulması için 8 - 10 dakika süre yeterli olmaktadır. Araştırma kapsamında toplanan veriler bilgisayar ortamına aktarılmıştır. Araştırmada verilerin değerlendirilmesi için SPPS 26,0 (Statistical Programme for Social Sciences) paket programı kullanılmıştır. Verilerin normallik dağılımına Kolmogorov-Smirnov testiyle bakılmıştır. Veriler \%95 güvenle normal dağılımlıdır. Verilerin analizinde parametrik testler kullanılarak; Bağımsız Gruplarda t testi, tek yönlü varyans analizi (ANOVA) ve Pearson Korelasyon testinden 
yararlanılmıştır. ANOVA testinde gruplar arası farklılığın tespiti için Post-Hoc testlerinden Tukey HSD ve Dunnett T3 kullanılmıştır. İstatistiksel anlamlılık seviyesi olarak 0,05 değeri baz alınmış olup $\mathrm{p}<0,05$ olması durumunda anlamlı bir farklılığın olduğu, p>0,05 olması durumunda ise anlamlı bir farklılığın olmadığı belirlenmiştir (Kalayc1, 2010).

\section{Bulgular}

Verilerden elde edilen bulgular araştırma sorularına göre tablolar halinde sirasiyla verilmiştir.

Tablo 2: Sanal Ortam Yalnızlı̆̆ının Demografik Değişkenlere Göre Farklılık Analizi

\begin{tabular}{|c|c|c|c|c|c|}
\hline & Özellikler & SOYÖ & $\begin{array}{c}\text { Sanal } \\
\text { Sosyalleșme }\end{array}$ & $\begin{array}{c}\text { Sanal } \\
\text { Paylaşım }\end{array}$ & $\begin{array}{c}\text { Sanal } \\
\text { Yalnızlık }\end{array}$ \\
\hline \multirow{2}{*}{ Cinsiyet } & Kadın & $2,74 \pm 0,60$ & $3,12 \pm 0,81$ & $2,12 \pm 0,95$ & $3,38 \pm 0,75$ \\
\hline & Erkek & $2,90 \pm 0,61$ & $3,16 \pm 0,88$ & $2,36 \pm 0,89$ & $3,23 \pm 0,69$ \\
\hline$t$ & & 0,90 & 0,44 & 2,33 & 1,93 \\
\hline$p$ & & 0,044 & 0,658 & 0,200 & 0,540 \\
\hline \multirow{2}{*}{ Yaş } & Ortalama altı & $2,83 \pm 0,56$ & $3,14 \pm 0,81$ & $2,10 \pm 0,83$ & $3,25 \pm 0,75$ \\
\hline & Ortalama üstü & $2,88 \pm 0,64$ & $3,13 \pm 0,85$ & $2,28 \pm 1,01$ & $3,30 \pm 0,73$ \\
\hline$t$ & & 0,54 & 0,25 & 3,57 & 0,40 \\
\hline$p$ & & 0,462 & 0,874 & 0,059 & 0,525 \\
\hline Öğrenim & Sağlık Bilimleri $^{1}$ & $2,91 \pm 0,63$ & $3,20 \pm 0,90$ & $2,29 \pm 0,93$ & $3,29 \pm 0,71$ \\
\hline Görülen & Sağlık Hiz.Mes. ${ }^{2}$ & $2,84 \pm 0,60$ & $3,08 \pm 0,82$ & $2,15 \pm 0,82$ & $3,42 \pm 0,75$ \\
\hline Birim & Hemşirelik $^{3}$ & $2,82 \pm 0,58$ & $3,12 \pm 0,77$ & $2,16 \pm 1,05$ & $3,27 \pm 0,75$ \\
\hline$F$ & & 0,68 & 0,66 & 0,94 & 1,68 \\
\hline \multirow[t]{2}{*}{$p$} & & 0,507 & 0,515 & 0,388 & 0,187 \\
\hline & $0-2000 E^{1}$ & $2,94 \pm 0,59$ & $3,15 \pm 0,77$ & $2,37 \pm 1,01$ & $3,39 \pm 0,73$ \\
\hline Aylık & $2001-3000 E^{2}$ & $2,91 \pm 0,62$ & $3,21 \pm 0,85$ & $2,24 \pm 0,95$ & $3,38 \pm 0,74$ \\
\hline \multirow[t]{2}{*}{ Gelir } & $3001-4000 €^{3}$ & $2,81 \pm 0,57$ & $3,09 \pm 0,85$ & $2,17 \pm 0,86$ & $3,23 \pm 0,71$ \\
\hline & $4001+\mathbf{E}^{4}$ & $2,76 \pm 0,64$ & $3,07 \pm 0,84$ & $2,03 \pm 0,92$ & $3,31 \pm 0,77$ \\
\hline$F$ & & 1,66 & 0,61 & 1,93 & 0,92 \\
\hline$p$ & & 0,173 & 0,604 & 0,124 & 0,431 \\
\hline \multirow{3}{*}{$\begin{array}{l}\text { Barınma } \\
\text { Durumu }\end{array}$} & Aile $^{1}$ & $2,82 \pm 0,63$ & $3,11 \pm 0,85$ & $2,13 \pm 0,96$ & $3,31 \pm 0,77$ \\
\hline & Arkadaş $^{2}$ & $2,92 \pm 0,56$ & $3,20 \pm 0,82$ & $2,28 \pm 0,86$ & $3,36 \pm 0,69$ \\
\hline & Yalnız ${ }^{3}$ & $3,12 \pm 0,45$ & $3,14 \pm 0,67$ & $2,68 \pm 0,88$ & $3,31 \pm 0,53$ \\
\hline$F$ & & 1,71 & 0,39 & 3,78 & 0,15 \\
\hline$p$ & & $\mathbf{0 , 0 3 1}$ & 0,674 & 0,024 & 0,860 \\
\hline Post-Hoc & & $1<3 \mathrm{a}$ & & $1<2,3 \mathrm{~b}$ & \\
\hline
\end{tabular}

Post-Hoc testleri a=Tukey HSD b=Dunnett T3 
Katılımcıların Sanal Ortam Yalnızlığı ölçeğinden aldıkları puanlar ile temel demografik özelliklerinin karşılaştırılması Tablo 2'de verilmiştir. Sanal Ortam Yalnızlığı ile yaş, eğitim görülen birim ve aylık gelir durumu arasında istatistiksel olarak anlamlılık saptanmamıştır ( $p>0,05$ ). Kadınların erkekler göre göre, ailesiyle birlikte yaşayanların yalnız yaşayanlara göre sanal ortam yalnızlığı seviyelerinin daha düşük olduğu tespit edilmiştir $(p<0,05)$. Sanal Sosyalleşme ve Sanal Yalnızlık alt boyutları ile katılımcıların temel demografik özellikleri arasında istatistiksel olarak anlamlılık saptanmamıştır ( $p>0,05)$. Sanal Paylaşım alt boyutu ile cinsiyet, yaş, ögrenim görülen birim ve aylık gelir durumu arasında istatistiksel olarak anlamlılık saptanmamışırı $(\mathrm{p}>0,05)$. Ailesiyle birlikte yaşayanların arkadaşlarıyla yaşayanlar ve yalnız yaşayanlara göre sanal paylaşım seviyelerinin daha düşük olduğu tespit edilmiştir $(\mathrm{p}<0,05)$.

Tablo 3: Özgüvenin Demografik Değişkenlere Göre Farklılık Analizi

\begin{tabular}{|c|c|c|c|c|}
\hline Özellikler & & Özgüven Ölçeği & İç Özgüven & Dış Özgüven \\
\hline \multirow{2}{*}{ Cinsiyet } & Kadın & $3,60 \pm 0,59$ & $3,84 \pm 0,59$ & $3,75 \pm 0,66$ \\
\hline & Erkek & $3,87 \pm 0,48$ & $3,88 \pm 0,50$ & $3,86 \pm 0,52$ \\
\hline$t$ & & 1,31 & 0,58 & 1,89 \\
\hline$p$ & & $\mathbf{0 , 0 3 0}$ & 0,561 & 0,059 \\
\hline \multirow{2}{*}{ Yaş } & Ortalama altı & $3,77 \pm 0,52$ & $3,81 \pm 0,52$ & $3,72 \pm 0,60$ \\
\hline & Ortalama üstü & $3,86 \pm 0,58$ & $3,89 \pm 0,59$ & $3,84 \pm 0,63$ \\
\hline$t$ & & 2,95 & 1,92 & 3,47 \\
\hline$p$ & & 0,087 & 0,167 & 0,063 \\
\hline Öğrrenim & Sağlık Bilimleri ${ }^{1}$ & $3,88 \pm 0,59$ & $3,91 \pm 0,58$ & $3,84 \pm 0,65$ \\
\hline Görülen & Sağlık Hiz.Mes. ${ }^{2}$ & $3,74 \pm 0,49$ & $3,76 \pm 0,51$ & $3,73 \pm 0,55$ \\
\hline Birim & Hemşirelik $^{3}$ & $3,84 \pm 0,59$ & $3,89 \pm 0,58$ & $3,78 \pm 0,65$ \\
\hline$F$ & & 2,00 & 2,85 & 1,11 \\
\hline$p$ & & 0,036 & 0,059 & 0,330 \\
\hline Post-Hoc & & $2<1,3 \mathrm{~b}$ & & \\
\hline \multirow{4}{*}{ Aylık Gelir } & $0-2000 £^{1}$ & $3,85 \pm 0,54$ & $3,89 \pm 0,54$ & $3,80 \pm 0,60$ \\
\hline & $2001-3000 £^{2}$ & $3,79 \pm 0,58$ & $3,82 \pm 0,57$ & $3,76 \pm 0,66$ \\
\hline & $3001-4000 \underbrace{3}$ & $3,84 \pm 0,55$ & $3,87 \pm 0,56$ & $3,80 \pm 0,59$ \\
\hline & $4001+E^{4}$ & $3,82 \pm 0,57$ & $3,85 \pm 0,58$ & $3,79 \pm 0,61$ \\
\hline$F$ & & 0,22 & 0,29 & 0,13 \\
\hline p değeri & & 0,878 & 0,832 & 0,937 \\
\hline
\end{tabular}




\begin{tabular}{llccc}
\hline Barınma & Aile $^{\mathbf{1}}$ & $3,79 \pm 0,55$ & $3,82 \pm 0,56$ & $3,76 \pm 0,61$ \\
Durumu & Arkadaş $^{2}$ & $3,90 \pm 0,56$ & $3,94 \pm 0,55$ & $3,86 \pm 0,61$ \\
& Yalnız $^{\mathbf{3}}$ & $3,80 \pm 0,63$ & $3,83 \pm 0,59$ & $3,78 \pm 0,72$ \\
& & 1,36 & 1,51 & 0,97 \\
$p$ & & 0,258 & 0,221 & 0,377 \\
\hline
\end{tabular}

Post-Hoc testleri a=Tukey HSD b=Dunnett T3

Katılımcıların Özgüven ölçeğinden aldıkları puanlar ile temel demografik özelliklerinin karşılaştırılması Tablo 3'te verilmiştir. Özgüven ile yaş, aylık gelir durumu ve barınma durumu arasında istatistiksel olarak anlamlılık saptanmamıştır ( $>0,05)$. Kadınların erkeklere göre, Sağlık Hizmetleri MYO öğrencilerinin Sağlık Bilimleri Fakültesi ve Hemşirelik Fakültesi öğrencilerine göre daha düşük özgüvene sahip oldukları tespit edilmiştir $(p<0,05)$. İç Özgüven ve Dış Özgüven alt boyutları ile katılımcıların temel demografik özellikleri arasında istatistiksel olarak anlamlılık saptanmamıştır ( $\mathrm{p}>0,05)$.

Tablo 4: Sanal Ortam Yalnızlık Ölçeği ile Özgüven Ölçeği Arasında Korelasyon Analizi

\begin{tabular}{llcccc}
\hline & & SOYÖ & $\begin{array}{c}\text { Sanal } \\
\text { Sosyalleşme }\end{array}$ & $\begin{array}{c}\text { Sanal } \\
\text { Paylaşım }\end{array}$ & $\begin{array}{c}\text { Sanal } \\
\text { Yalnızlık }\end{array}$ \\
\hline \multirow{2}{*}{ Özgüven Ölçeği } & $\mathbf{r}$ & $-0,469^{*}$ & $-0,297$ & 0,015 & $-0,006$ \\
& $\boldsymbol{p}$ & $<\mathbf{0 , 0 0 1}$ & $<\mathbf{0 , 0 0 1}$ & 0,766 & 0,903 \\
\hline \multirow{2}{*}{ İç Özgüven } & $\mathbf{r}$ & 0,114 & 0,245 & $-0,021$ & $-0,031$ \\
& $\boldsymbol{p}$ & 0,025 & $<\mathbf{0 , 0 0 1}$ & 0,677 & 0,544 \\
\hline \multirow{2}{*}{ Dış Özgüven } & $\mathbf{r}$ & $-0,206$ & 0,317 & 0,049 & 0,018 \\
& $\boldsymbol{p}$ & $<\mathbf{0 , 0 0 1}$ & $\mathbf{< 0 , 0 0 1}$ & 0,339 & 0,720 \\
\hline
\end{tabular}

* Korelasyon 0,05 düzeyinde anlamlıdır.

Katılımcıların Sanal Ortam Yalnızlı̆̆ı ve Özgüven ölçekleri ile alt boyutlar1 arasında yapılan korelasyon analizi sonuçları Tablo 4'te sunulmuştur. Özgüven ile Sanal Ortam Yalnızlığı ile negatif yönde zayıf düzeyde, Sanal Sosyalleşme pozitif yönde zayıf düzeyde anlamlı bir ilişki tespit edilmiştir $(p<0,05)$. Özgüven ile Sanal Paylaşım ve Sanal Yalnızlık arasında istatistiksel olarak anlamlı bir ilişki tespit edilememiştir ( $>0,05)$. İç Özgüven ile Sanal Ortam Yalnızlığı ve Sanal Sosyalleşme pozitif yönde çok zayıf düzeyde anlamlı bir ilişki tespit edilmiştir $(\mathrm{p}<0,05)$. İç Özgüven ile Sanal Paylaşım ve Sanal Yalnızlık arasında istatistiksel olarak anlamlı bir ilişki tespit edilememiştir ( $p>0,05)$. Dış Özgüven ile Sanal Or- 
tam Yalnızlığı ile pozitif yönde çok zayıf düzeyde, Sanal Sosyalleşme pozitif yönde zayıf düzeyde anlamlı bir ilişki tespit edilmiştir $(p<0,05)$. Dış Özgüven ile Sanal Paylaşım ve Sanal Yalnızlık arasında istatistiksel olarak anlamlı bir ilişki tespit edilememiştir $(\mathrm{p}>0,05)$

\section{Tartışma}

Bu çalışma Selçuk Üniversitesinde seçilen 3 fakültedeki öğrencilerin sanal ortam yalnızlık durumu ile özgüvenleri arasındaki ilişki durumunu ölçmek amacıyla yapılmıştır. Araştırmaya katılan öğrenciler; \%66,2'si kadın ve \%33,8'i erkek

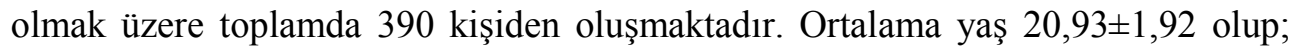
$\% 54,4$ 'ü ortalama yaş üzerindedir.

Araştırmada kapsamında olan öğrencilerin, Sanal Ortam Yalnızlığı ölçeği ortalama puanlarının cinsiyete göre karşılaştırıldığında erkek öğrencilerin Sanal Ortam Yalnızlığının kadın öğrencilere göre daha yüksek seviyede olduğu görülmüştür. Konuyla ilgili yapılan çalışmalar bulgumuzu destekler niteliktedir (Çeçen, 2007; Özen ve Sarıc1, 2010; Bingöl, 2017). Sanal Ortam Yalnızlı̆̆ının erkek öğrencilerde daha yüksek olmasının sebebi olarak erkeklerde yalnızlık duygusunun daha etkili olması düşünülmektedir. Araştırmada erkek öğrencilerin Sanal Paylaşım ve Sanal Sosyalleşme puanlarının daha yüksek olduğu tespit edilmiştir. Bu durum yalnızlık duygusunun dışavurumu olarak düşünülebilir. Özen ve Sarıcı (2010) üniversiteli erkek öğrencilerin, kızlara oranla sanal sohbet ortamlarını yalnızlıklarına destek unsuru olarak daha çok kullandıkları, yalnız hisseden erkeklerin daha çok çevrimiçi arkadaş edindikleri ve çevrimiçi arkadaşlıklarıyla daha çok zaman geçirip problemlerini paylaştıkları, bir nevi sanal arkadaşlıklara daha bağımlı olduklarını belirlemiştir. Öğrencilerin barınma durumuna göre Sanal Ortam Yalnızlığı seviyelerinin karşılaştırılmasında ise yalnız yaşayan öğrencilerin, ailesiyle birlikte olanlara ve arkadaşları ile yaşayanlara göre daha yüksek Sanal Ortam Yalnızlığı yaşadıkları tespit edilmiştir. Bu durum öğrencilerin aileleriyle birlikteyken yalnızlık duygusunu daha az hissettiklerini düşündürmektedir. 
Öğrencilerin Özgüven ölçeği ortalama puanlarının cinsiyete göre karşılaştırıldığında erkek öğrencilerin özgüvenleri kadın öğrencilere göre daha yüksek seviyede olduğu tespit edilmiştir. Sarıçam ve Güven (2012) üniversite öğrencilerine yaptıkları çalışmada da benzer sonuçları bulmuştur. Benzer sonuçlara Çelik (2014) yapmış olduğu çalışmada da rastlanmıştır. Bu bulgular bizim araştırma sonucu ile paralellik göstermektedir. Cinsiyet değişkenine göre anlamlı farklılık olmayan araştırmalar da mevcuttur (Soysal, 2014; Karademir, 2010). Özgüven ile öğrenim görülen birim arasında anlamlı bir farklılık tespit edilmiştir. Sağlık Bilimleri ve Hemşirelik Fakültesi öğrencilerinin Sağlık Hizmetleri Meslek Yüksekokulu öğrencilerine göre özgüveni daha yüksek bulunmuştur.

Sanal Ortam ölçeği ve alt boyutları ile Özgüven ölçeği ve alt boyutları arasında yapılan Korelasyon analizine göre negatif yönde ilişki bulunmaktadır. Sanal Ortam Yalnızlık seviyesindeki artış Özgüven seviyesini zayıf düzeyde de olsa etkilemektedir. Özgüven ölçeği dış özgüven alt boyutu ile Sanal Ortam Yalnızlık ölçeğinin en yakın ilişkili olduğu alt boyut olarak tespit edilmiştir. Öğrencilerin özgüven seviyesi arttıkça Sanal ortamlarda geçirdiği süre azalmaktadır.

\section{Sonuç}

Sonuç olarak sosyal ağlar ve ortamlar, bireylerin kendilerinde eksik hissettiği duygulara hitap etmektedir. Birey, her ne kadar bu yöntemlerle yalnızlığını giderdiği duygusuna kapılsa da aslında gerçek öyle değildir. Teknolojik aletleri kapattıkları an itibari ile kişiler tekrar tek başına kalmakta ve yalnızlıkla yüzleşmektedir. Bu gerçek, yalnızlık duygusunu, sanal ortamda yaşadığı yalnızlık duygusu ile beraber daha da derin hale getirecektir. Sağlık bilimleri, Hemşirelik Fakültesi ve Sağlık Meslek Yüksek Okulundaki öğrenciler üzerinde uygulanmış olan bu çalışma ile öğrencilerin şiddetli olmamakla birlikte sanal ortam yalnızlığı yaşadığı sonucu elde edilmiştir. Aynı zamanda öğrencilerin sanal yalnızlık ve sanal sosyalleşme eğilimlerinin de diğer boyutlara oranla daha yüksek seviyede olduğu görülmüştür. Anlaşılan o ki, öğrenciler sanal ortamlar üzerinden sosyal arkadaşlıklar edinerek, bu ortamlarda iletişim kurma eğilimi göstermektedir. Bu eğilimler sonucunda orta- 
ya çıkacak sanal arkadaşlıklarla ve devamı olmayan bu arkadaş ve dostluklarla birlikte bireylerin daha fazla yalnızlaştığı görülecektir. Üniversiteler ve öğrenci ile alakası olan her kurum bu doğrultuda öğrencileriyle iletişim noktasında sosyal medya araçlarını kullanarak, öğrencilerin sıkıntılarını anlamaya, eğitim açısından bazı geri dönüşlerde bulunmaya çalışabilecektir. Bu yollarla kurulan iletişim öğrencilerin ilgisini daha çok çekerek, öğrencileri doğru biçimde yönlendirme konusunda yardımcı olabilecektir. Ayrıca sanal ortam içinde yalnızlık yaşayan öğrenci ve bireylerin özgüven düzeyleri ele alınarak incelenmesi ve eğitim verilen kurumlarda öğrenciye özgüven aşılaması yapılması da artı bir yarar katacaktır.

\section{Kaynakça}

Akın, A. (2007). Öz-güven ölçeğinin geliştirilmesi ve psikometrik özellikleri. Abant İzzet Baysal Üniversitesi Eğitim Fakültesi Dergisi, 7 (2), 167-176.

Altunışık, R., Coşkun, R., Bayraktaroğlu, S., \& Yıldırım, E. (2012). Sosyal bilimlerde araştırma yöntemleri. İstanbul: Sakarya Kitabevi.

Başoğlu, S. T. (2007). Sinav kaygısı ile özgüven arasındaki ilişkinin erinlik döneminde incelenmesi. Yayımlanmamış yüksek lisans tezi, İstanbul: Maltepe Üniversitesi Sosyal Bilimler Enstitüsü.

Bingöl, A. (2017). Virtual environment loneliness as a predictor of academic achievement. Presented at the 8th International Advanced Technologies Symposium, Elâzı̆g.

Çeçen, A. R. (2007). Üniversite öğrencilerinin cinsiyet ve yaşam doyumu düzeylerine göre sosyal ve duygusal yalnızlık düzeylerinin incelenmesi. Mersin Üniversitesi Eğitim Fakültesi Dergisi, 3 (2), 180-190.

Çelik, İ. (2014). Ortaokul ögrencilerinin özgüven düzeyinin bazı değişkenler açısından değerlendirilmesi Afyonkarahisar örneği. Yayımlanmamış yüksek lisans tezi, Ankara: Türk Hava Kurumu Üniversitesi Sosyal Bilimler Enstitüsü.

Çevikbaş, M. (2013). Matematik ögrretmenlerinin yanlışa verdikleri dönütlerin ögrrenci özgüvenleri üzerindeki etkilerinin incelenmesi. Yayımlanmamış yüksek lisans tezi, Ankara: Gazi Üniversitesi Eğitim Bilimleri Enstitüsü.

Erözkan, A. (2009). The predictors of loneliness in adolescents. İköretim Online, 8 (83), 809-819.

Erpalabıyık, B. Okçu, V. (2019). Üniversite öğrencilerinin gençlik liderlik özellikleri ile benlik saygısı ve özgüven algıları arasındaki ilişkilerin incelenmesi. Journal Of Social, Humanities and Administrative Sciences, 5 (15), 228-243. 
Gökkaya, D. ve Biçer, T. (2017). Psikolojik beceri kıstası olarak özgüvenin, elit sporcuların performansına katkısı; boks milli takımı örneği. Marmara Üniversitesi Spor Bilimleri Dergisi, 2 (1), 16-28.

Göknar, N. T. (2010). Down sendromlu türk çocuklarında büyüme ĕgrilerinin belirlenmesi. Yayımlanmamış tıpta uzmanlık tezi, İstanbul: İstanbul Ünv. Cerrahpaşa Tıp Fak.

Günalp, A. (2007). Farklı anne baba tutumlarının okul öncesi eğitim çağındaki çocukların özgüven duygusunun gelişimine etkisi (Aksaray ili örneği). Yayımlanmamış yüksek lisans tezi, Konya: Selçuk Üniversitesi Sosyal Bilimler Enstitüsü.

Kabaklı Çimen, L. (2018). Üniversite öğrencilerinin internet bağımlılığı ile sanal ortam yalnızlık düzeyleri arasında ilişkinin incelenmesi. Elektronik Sosyal Bilimler Dergisi, 17 (68), 1431-1452.

Kalaycı, Ş. (2010). SPSS uygulamalı çok değişkenli istatistik teknikleri. Ankara: Asil Yay. Dağ.

Karademir, N., (2010). Coğrafya öğretmenlerinin alanlarına ilişkin öz yeterlik algılarının incelenmesi. e-Journal of New World Sciences Academy Education Sciences, 1C0254, 5 (4), 2034-2048.

Korkmaz, Ö., Usta, E., \& Kurt, İ. (2014). Sanal ortam yalnızlık ölçeği (soyö) geçerlik ve güvenirlik çalışması. Hacettepe Üniversitesi Eğitim Fakültesi Dergisi, 29 (2), 144-159.

Kurtuldu, P. S. (2007). Illkögretim okulu yöneticilerinin özgüven düzeyleri ile liderlik düzeyleri arasındaki iliş̧kinin incelenmesi. Yayımlanmamış yüksek lisans tezi, İstanbul: Yeditepe üniversitesi Sosyal Bilimler Enstitüsü.

Morahan-Martin, J. (1999). The relationship between loneliness and internet use and abuse. $C y$ ber Psychology and Behavior, 2, 431-440.

Özdemir, S., Akçakanat, T. ve İzgüden, D. (2017). İnternet çağında sanal ortam yalnızlığı üniversite öğrencileri üzerine bir araştırma. Süleyman Demirel Üniversitesi Vizyoner Dergisi, 8 (19), 125-136.

Özen, Ü. ve Sarıcı, M. B. (2010). Yalnızlık olgusu ve sanal sohbetin yalnızlığın paylaşımına etkisi: üniversite öğrencileri üzerinde bir araştırma. Atatürk Üniversitesi İktisadi ve İdari Bilimler Dergisi, 24 (1), 149-158.

Sarıçam, H. ve Güven,M. ( 2012 ). Özgüven ve dini tutum. The Journal of Academic Social Science Studies, 5 (7), 573-586.

Soysal, M.R., (2014). Sinıf ögrretmenliği ana bilim dalı ögrencilerinin öğretmenlik mesleği öz yeterlik inançları.Yayımlanmamış yüksek lisans tezi, Bolu: Abant İzzet Baysal Üniversitesi Eğitim Bilimleri Enstitüsü.

Weiss, R. S. (1973). Loneliness: the experience of emotional and social tsolation. MIT Press: Cambridge. 